\title{
Adverse health effects of spousal violence among women attending Saudi Arabian primary health-care clinics
}

H.M. Eldoseri, ${ }^{1}$ K.A. Tufts, ${ }^{2}$ Q. Zhang ${ }^{2}$ and J.N. Fish ${ }^{3}$

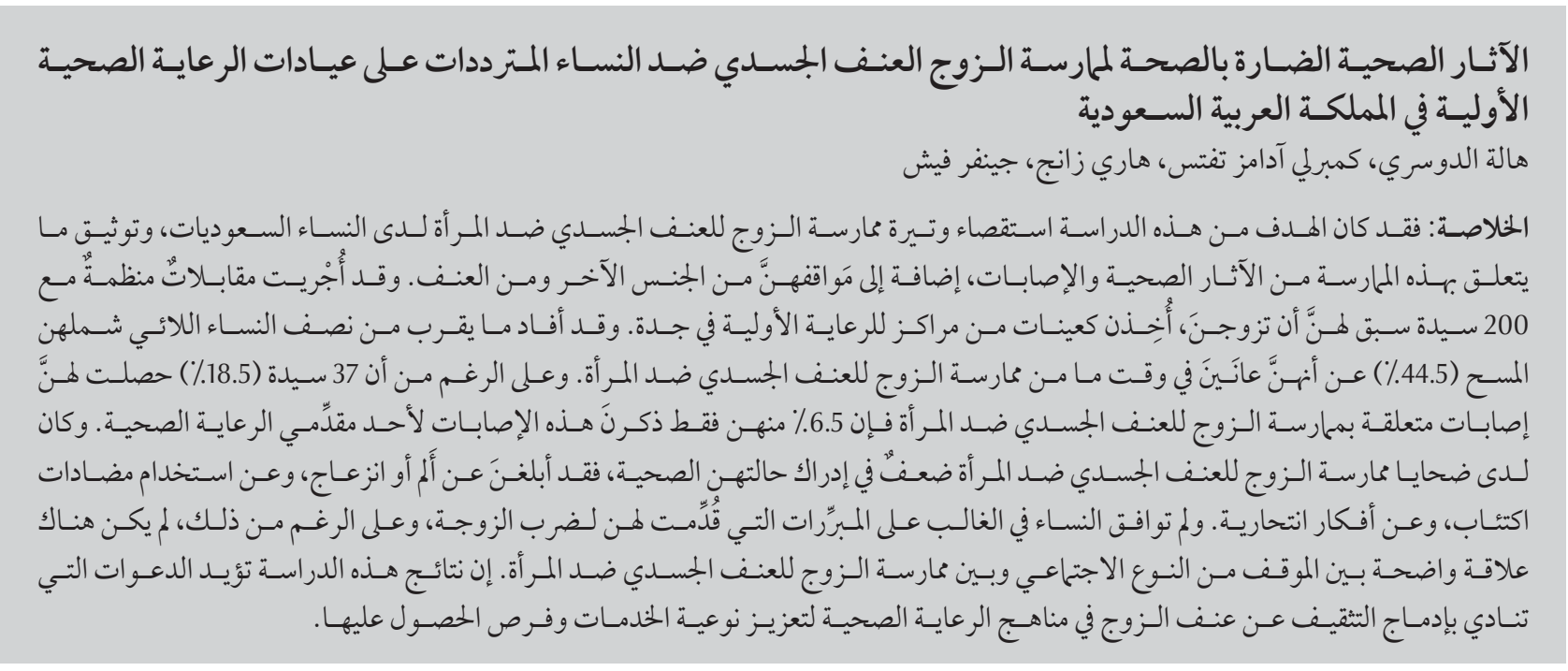

ABSTRACT This study aimed to investigate the frequency of spousal violence among Saudi women and document the related health effects and injuries, as well as their attitudes to gender and violence. Structured interviews were conducted with 200 ever-married women recruited from primary-care centres in Jeddah. Nearly half of the surveyed women (44.5\%) reported ever experiencing physical violence from their spouse. Although 37 women (18.5\%) had received violencerelated injuries, only $6.5 \%$ had reported these injuries to a health-care provider. Victims of spousal violence had poor perceptions of their overall health, and reported pain or discomfort, antidepressant use and suicidal thoughts. Women mostly disagreed with the presented justifications for wife-beating. However, the association between gender attitudes and spousal violence was not significant. The results of this study support calls for integration of education about partner violence into health-care curricula to enhance the access and quality of services.

Effets indésirables de la violence conjugale sur la santé des femmes consultant dans des centres de soins de santé primaires en Arabie saoudite

RÉSUMÉ La présente étude visait à examiner la fréquence de la violence physique infligée par les conjoints à des femmes saoudiennes et de documenter les effets sur la santé et les traumatismes qui y sont liés, ainsi que leurs attitudes vis-à-vis du sexisme et de la violence. Des entretiens structurés ont été menés auprès de 200 femmes ayant déjà été mariées, recrutées dans des centres de soins de santé primaires à Djedda. Près de la moitié des femmes ayant participé à l'enquête (44,5 \%) ont déclaré avoir déjà été victimes de violence conjugale. Pourtant, si 37 femmes (18,5 \%) ont présenté des traumatismes liés à la violence physique infligée par leur conjoint, seules 6,5\% avaient consulté un prestataire de soins de santé pour ce motif. Les victimes de violence conjugale avaient une perception médiocre de leur état de santé en général et affirmaient souffrir de douleur et de gêne, consommer des antidépresseurs et avoir des idées suicidaires. Les femmes interrogées étaient le plus souvent en désaccord avec les justifications proposées pour la violence conjugale. Toutefois, l'association entre les attitudes sexistes et la violence conjugale n'était pas significative. Les résultats de cette étude confirment la nécessité d'inclure une formation sur la violence conjugale dans les programmes d'études sur les soins de santé afin d'accroître l'accès aux services et leur qualité.

${ }^{1}$ School of Nursing, Johns Hopkins University, Baltimore, Maryland, United States of America (Correspondence to H. Eldoseri: heldo001@gmail. com). ${ }^{2}$ College of Health Sciences, ${ }^{3}$ College of Arts and Letters, Old Dominion University, Virginia, United States of America.

Received: 15/08/13; accepted: 06/05/14 


\section{Introduction}

Spousal violence refers to a range of physically coercive or violent acts used against adult and adolescent women by current or former spouse (1). It is considered not only a human rights violation but also a serious public health concern (2). The World Health Organization (WHO) asserts that spousal violence, "occurs in all countries, irrespective of social, economic, religious or cultural group" (3). Variations in prevalence of spousal violence between different countries have been documented, pointing to the importance of establishing correlates of spousal violence across different populations $(4,5)$. Most importantly, the variation suggests that spousal violence is a modifiable and preventable phenomenon that may be amenable to culturally relevant interventions including those aimed at persons living in the Eastern Mediterranean Region (EMR).

In the EMR and particularly in Arab societies, both universal and culturespecific factors may put women to greater risk for spousal violence. Laws and public policy that reflect gender inequities, mandate divorce restrictions and support patriarchal societies lead to increased risks for violence. Women may also be discouraged from reporting abuse to health-care professionals or legal authorities due to the social importance given to maintaining marital status. Reports of abuse are often denied, minimized, interpreted as delusional or ignored (6). As a result, health-care professionals often under-report and/ or fail to detect and document abuse. Nevertheless, some studies conducted in EMR countries have documented different aspects of spousal violence (7-11). The observed variation in the prevalence of spousal violence across MR countries can be attributed not only to variations in methods of data collection but to the cultural and societal differences influencing the perspectives of the populations studied. Regional assessments, therefore, must take into account the national and cultural diversity of any research focused on spousal violence.

Little formal research, a paucity of statistical data and a virtual absence of official records on spousal violence in Saudi Arabia create a pressing need for focused investigation The small number of studies that have been conducted used broader definitions that measured different manifestations of gender-based violence, including domestic violence defined as emotional, physical and sexual violence perpetrated by anyone against women (12), the impact of physical violence during pregnancy (13), and physical and emotional violence in ever-married women (14). Such limited reporting fails to offer an accurate picture of the Saudi Arabian case, where the impact of spousal violence presents serious and disproportionate health concerns for women.

The documented relationship between spousal violence and adverse health effects underscores that this issue merits attention (15). Studies in the EMR have documented the deleterious health effects of spousal violence including negative maternal and child health outcomes $(16,17)$. The association between spousal violence and impaired mental health, physical injuries, disability and death has also been documented in several studies conducted in the EMR (18-21). Violence against women is embedded in beliefs and attitudes about gender roles. In one Saudi Arabian study, half of the men supported the use of violence against women in cases of misconduct and a third of men actually resorted to violence to deal with a wife's misbehaviour. Interestingly, a third of the women in the same study agreed with the use of violence in cases of women's misconduct (22).

The purpose of this study was therefore to utilize the primary health care (PHC) setting to assess: the frequency and types of spousal violence; the association between reported spousal violence and adverse health effects; the types of injuries sustained; and if women discussed spousal violence with health-care professionals at the PHC. Additionally, we extended the study by exploring Saudi women's gender attitudes and acceptance of spousal violence under certain hypothetical scenarios in the context of marriage.

\section{Methods}

This exploratory study was cross-sectional in nature. The data were collected via structured interviews in PHCs in Jeddah, Saudi Arabia, between March and June 2012. The primary investigator conducted the interviews in Arabic and utilized her knowledge of cultural norms to navigate the PHC systems.

\section{Sampling}

A power analysis revealed that a minimum sample size of 132 was needed to achieve a power of 0.90 with an effect size of 0.4 and alpha set at 0.05 . An increase in the sample size to 200 women was conducted to account for underreporting. In each region, we targeted a sample size of 40 women for individual interviews. PHCs were selected from each of the 5 regions of the city; namely, north, south, east, west and central to enhance geographic representation of the study participants. However, due to logistics and research time constraints, we opted for convenience rather than random sampling of PHCs. The principal investigator sought to recruit women from PHCs in reachable locations, with cooperative managers, private areas for one-to-one interviews and the potential to receive at least 40 women visitors per week. In cases where the number of women interviewed in any PHC was less than 40 in 2 weeks, another PHC was selected from the same region to complete the 40 interviews per region. A total of 6 PHCs were selected, including $2 \mathrm{PHCs}$ from northern region, out of a total 80 PHCs in Jeddah to recruit 40 participants from each region. 
A flyer was used at the reception of the selected PHCs to invite eligible women to participate. The flyer stated the purpose of the study, emphasized the voluntary nature of participation, detailed the inclusion criteria, stressed confidentiality and included contact information for the study investigator. Interested women were directed to the study investigator to screen them for eligibility. Women were included in the study if they were: of Saudi nationality; married, divorced or widowed; between the ages of 18-65 years; and in receipt of health care at the selected PHC. Women who were never married or who had family members who had already participated in the study were excluded from participation. The latter condition was made to protect women from potential retaliation. In addition, the study was always referred to as the "Survey on Women's Health and Life Experiences". One-to-one interviews were conducted with consenting women at the end of their PHC visits. Thirteen women did not complete the interview process because they had to be picked up immediately by their husbands or did not show up after the end of their visits.

\section{Data collection}

\section{Measures}

A 73-item adapted version of the WHO Violence against Women questionnaire (version 10.0) was used. The original questionnaire is made up of $12 \mathrm{sec}$ tions covering: the respondent and her family; general health; reproductive health; children; current or most recent partner; attitudes towards gender roles; respondent and her partner; injuries; impact and coping; past experience; financial autonomy; and completion of the interview. For the purpose of this study, sections 3, 4 and 9 (on reproductive health, children and impact and coping) were omitted. The questionnaire was translated into Arabic and then back-translated to English. The accuracy of language including idiom was assessed by an expert of Arabic. The internal consistency of the physical violence construct was good $(\alpha=0.82)$ and comparable with other studies utilizing the same questionnaire.

Spousal violence was measured by asking participating women the following question: "Has your husband ever: slapped you or thrown something at you that could hurt you?; pushed you or shoved you or pulled your hair?; hit you with his fist or with something else that could hurt you?; kicked you, dragged you or beaten you up?; choked or burnt you on purpose?; threatened to use or actually used a gun, knife, or other weapon against you?". In each act of spousal violence women were asked if the act happened in the past 12 months or ever, and the frequency (once, few times, several times). A woman who answered yes to any of the acts of spousal violence was considered exposed to spousal violence.

Women's attitudes about physical chastisement were explored by asking participating women if a husband has the right to beat his wife in 6 hypothetical scenarios: wife fails to do chores; wife disobeys husband; wife refuses to have sex; wife asks the husband if he is unfaithful; husband has doubts of his wife's fidelity; and wife actually commits adultery. Gender roles, whether progressive or traditional, were assessed by asking women if they agree or disagree with a series of statements. For example "a good wife obeys her husband even if she disagrees" and "it is important for a man to show his wife who is the boss". A woman accepting at least one of the scenarios was considered traditional in regard to gender attitudes.

\section{Protection of human subjects and ethical considerations}

The study proposal, protocol, flyer and notification statement were approved both by Old Dominion University research institutional review board and by Jeddah primary health-care administration in Saudi Arabia. A facilitation letter was issued by the PHC administration department to the study investigator to contact the selected PHCs and conduct the interviews with the eligible and consenting women. Investigators adhered to the ethical and safety guidelines for research on domestic violence against women (23). Due to the sensitive nature of this inquiry and the potential risk of retaliation, an institutional review board approved notification statement form was used instead of a signed consent form.

An Arabic notification statement was read by the study investigator for each consenting participant. The notification statement apprised all potential participants of the study's purpose, risks of participation, measures taken to ensure confidentiality, measures taken to minimize release of protected health information and the right to withdraw without penalty. A copy of the notification statement was given to the women if requested. After the interview was completed, each participant received a debriefing wherein they were asked not to divulge the nature of the study to anyone in order to protect them from potential retaliation. Referral cards with contact information and hotlines of women's shelters and social services were provided to each participant to address any potential needs arising from the interviews.

\section{Data analysis}

SPSS software, version 17.0, was used for data analysis. Univariate and multivariate analyses were conducted to describe the data. The chi-squared test for significance was used, with $P$ $<0.05$ considered significant. Logistic regression tests, including binary logistic regression and ordinal logistic regression, were conducted to analyse the significance of the relationship of spousal violence, women's health perceptions and gender attitudes. Odds ratio (OR) were calculated to assess the odds of perceived health status and gender attitudes associated with the reported spousal violence. 


\section{Results}

A total of 200 women participated in the study. Table 1 shows the socioeconomic characteristics of the participating women and their husbands. Most women and their husbands were educated. However, the majority of women were not wage-earners (73.0\%).

\section{Prevalence of spousal violence}

A higher proportion of women reported lifetime experience of spousal violence than in the last year; approximately half of women $89 / 200$ (44.5\%) reported ever experiencing spousal violence whereas 32/200 (16.0\%) reported experiencing spousal violence in the previous year (Figure 1). While acts of spousal violence varied in nature and severity, repeated acts of spousal violence were more common than single incidents (Figure 2).
Women whose husbands were employed were less likely to report spousal violence than those whose husbands were unemployed $(\mathrm{OR}=0.23$; $95 \% \mathrm{CI}$ : $0.08-0.67)$. However, no significant differences were observed in reports of spousal violence based on age and education of the women or their husbands (Table 1).

\section{Injuries related to spousal violence}

Nearly one-fifth of the women (37, $18.5 \%)$ stated that they had experienced injuries as a result of spousal violence including: cuts, abrasions, bites, scratches, bruises, dislocation, sprains, burns, deep cuts, wounds, broken eardrum, eye injuries, fractures, broken teeth and internal injuries. In addition, 8 of the women $(4.0 \%)$ reported other injuries such as hair being pulled out of the scalp and abortions related to spousal violence. Of the women, 31 had required medical attention for spousalviolence-related injuries and 19 had actually received it. In total, only 13 women $(6.5 \%)$ had told a health-care professional about the real cause of their injuries.

\section{Adverse health effects, health services utilization \& spousal violence}

In general, women who reported ever experience of spousal violence perceived that their health status was worse than did women who had never experienced spousal violence (Table 2). Spousal violence was less likely in women who reported very good or excellent overall health status (OR 0.5 ; 95\% CI: 0.3-0.9). In addition, spousal violence was twice as likely in women reporting recent feelings of pain or discomfort (OR 2.2; 95\% CI: 1.2-3.9).

\begin{tabular}{|c|c|c|c|c|c|c|c|c|}
\hline \multirow[t]{2}{*}{ Socioeconomic factors } & \multicolumn{2}{|c|}{ Total } & \multicolumn{2}{|c|}{ No spousal violence } & \multicolumn{2}{|c|}{ spousal violence } & \multirow[t]{2}{*}{ OR $(95 \% \mathrm{CI})$} & \multirow[t]{2}{*}{$P$-value } \\
\hline & No. & $\%$ & No. & $\%$ & No. & $\%$ & & \\
\hline \multicolumn{9}{|l|}{ Age of woman (years) } \\
\hline 18-30 (ref.) & 57 & 28.5 & 35 & 31.5 & 22 & 24.7 & & \\
\hline $31-50$ & 92 & 46.0 & 45 & 40.5 & 47 & 52.8 & $1.8(0.7-4.5)$ & 0.2 \\
\hline$\geq 51$ & 51 & 25.5 & 31 & 27.9 & 20 & 22.5 & $1.5(0.4-5.2)$ & 0.5 \\
\hline \multicolumn{9}{|l|}{ Age of husband (years) } \\
\hline 18-30 (ref.) & 23 & 11.5 & 14 & 12.8 & 9 & 10.3 & & \\
\hline $31-50$ & 109 & 54.5 & 55 & 50.5 & 54 & 62.1 & $0.9(0.3-2.9)$ & 0.9 \\
\hline$\geq 51$ & 64 & 32.0 & 40 & 36.7 & 24 & 27.6 & $0.6(0.2-2.7)$ & 0.6 \\
\hline \multicolumn{9}{|c|}{ Woman's education (years) } \\
\hline No education (ref.) & 30 & 15.0 & 20 & 18.0 & 10 & 11.2 & & \\
\hline$\leq 12$ & 114 & 57.0 & 56 & 50.5 & 58 & 65.2 & $2.4(0.8-7.4)$ & 0.12 \\
\hline$>12$ & 56 & 28.0 & 35 & 31.5 & 21 & 23.6 & $1.7(0.5-6.1)$ & 0.41 \\
\hline \multicolumn{9}{|c|}{ Husband's education (years) } \\
\hline No education (ref.) & 16 & 8.0 & 9 & 8.5 & 7 & 7.9 & & \\
\hline$\leq 12$ & 120 & 60.0 & 57 & 53.8 & 63 & 70.8 & $1.3(0.4-4.8)$ & 0.68 \\
\hline$>12$ & 59 & 29.5 & 40 & 37.7 & 19 & 21.3 & $0.7(0.2-2.7)$ & 0.55 \\
\hline \multicolumn{9}{|l|}{ Woman earns money } \\
\hline No (ref.) & 146 & 73.0 & 82 & 74.5 & 64 & 71.9 & & \\
\hline Yes & 53 & 26.5 & 28 & 25.5 & 25 & 28.1 & $1.0(0.5-2.1)$ & 0.97 \\
\hline \multicolumn{9}{|l|}{ Husband employed } \\
\hline No (ref.) & 26 & 13.0 & 8 & 7.3 & 18 & 20.9 & & \\
\hline Yes & 169 & 84.5 & 101 & 92.7 & 68 & 79.1 & $0.2(0.1-0.7)$ & 0.007 \\
\hline
\end{tabular}

Data were missing in some categories.

Ref. $=$ reference group; $O R=$ odds ratio; $C I=$ confidence interval . 


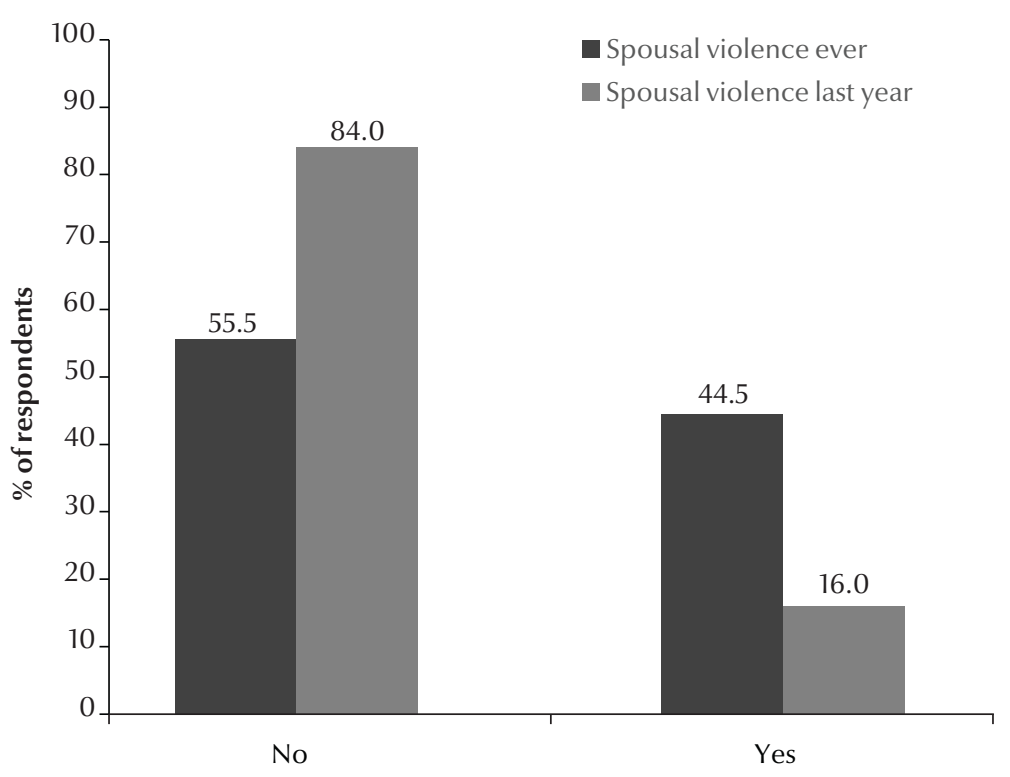

Figure 1 Spousal violence experienced in the previous year and ever, by the study sample of Saudi Arabian women $(n=200)$

Reports of spousal violence were 17 times more likely in women who reported recent intake of antidepressant drugs (OR 17.4; 95\% CI: 2-152) and 6.6 times more likely in women who had ever had suicidal thoughts (OR 6.6; 95\% CI: 2.4-17.9). No significant association was found between spousal violence and recent hospitalization or visits to health-care professionals.

\section{Women's attitudes to spousal violence}

Women who held traditional gender attitudes represented $44.0-80.5 \%$ of the sample (Table 3). Responses to 4 of the 5 questions showed that traditional and progressive gender attitudes were held fairly equally among the participants. The only exception was the women's views of interference of others outside the family; $161 / 200$ of the women $(80.5 \%)$ disagreed that others should interfere if a husband mistreats his wife. Most of the women did not accept wife-beating under most scenarios presented (83.5$98.5 \%$ ). The only exception was in the case of a wife's infidelity; in this situation 102/200 women (51.0\%) accepted the husband's right to beat his wife.

Our analysis revealed that ever experience of spousal violence was more likely in women with defiant/ progressive attitudes than in women with traditional attitudes, although the relationship was not generally

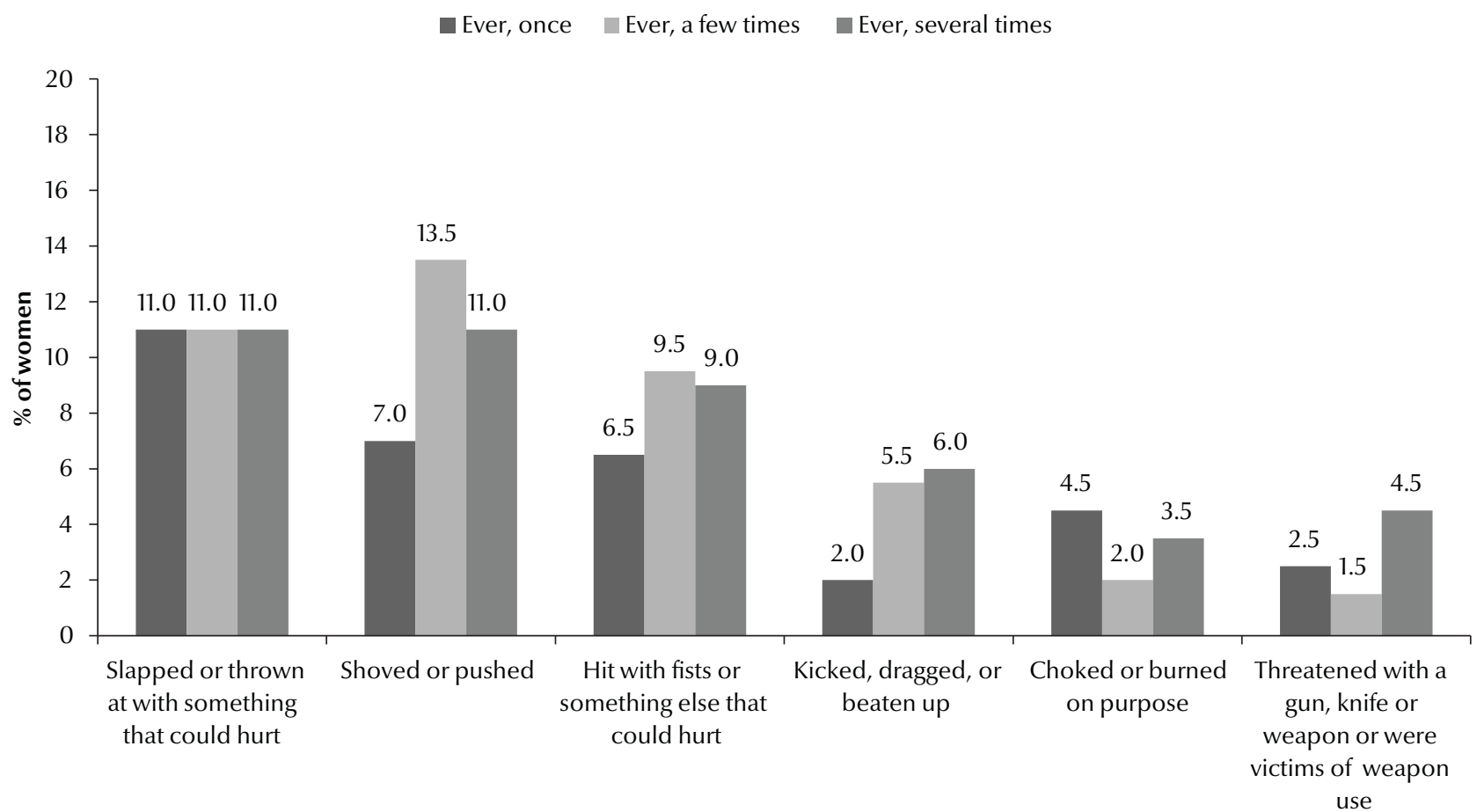

Figure 2 Types of spousal violence ever experienced by the study sample of Saudi Arabian women $(n=200)$ 


\begin{tabular}{|c|c|c|c|c|c|c|c|c|}
\hline \multirow[t]{2}{*}{ Women's perceived health indicator } & \multicolumn{2}{|c|}{ Total } & \multicolumn{4}{|c|}{ No spousal violence Spousal violence } & \multirow[t]{2}{*}{ OR $(95 \% \mathrm{Cl})$} & \multirow[t]{2}{*}{$P$-value } \\
\hline & No. & $\%$ & No. & $\%$ & No. & $\%$ & & \\
\hline \multicolumn{9}{|l|}{ Health perception } \\
\hline Very poor or poor & 14 & 7.0 & 6 & 5.4 & 8 & 9.0 & $0.5(0.3-0.9)$ & \multirow{3}{*}{0.02} \\
\hline Good & 70 & 35.0 & 33 & 29.7 & 37 & 41.6 & & \\
\hline Very good or excellent & 116 & 58.0 & 72 & 64.9 & 44 & 49.4 & & \\
\hline \multicolumn{9}{|l|}{ Movement in the past 4 weeks } \\
\hline No or few problems & 146 & 73 & 84 & 75.7 & 62 & 69.7 & \multirow[t]{3}{*}{$1.4(0.7-2.6)$} & \multirow[t]{3}{*}{0.3} \\
\hline Some problem & 41 & 20.5 & 22 & 19.8 & 19 & 21.3 & & \\
\hline Many problems or cannot walk at all & 13 & 6.5 & 5 & 4.5 & 8 & 9.0 & & \\
\hline \multicolumn{9}{|l|}{ Daily functions in the past 4 weeks } \\
\hline No or few problems & 164 & 82.0 & 91 & 82.0 & 73 & 82.0 & \multirow[t]{3}{*}{$1.0(0.5-2.0)$} & \multirow[t]{3}{*}{0.9} \\
\hline Some problems & 28 & 14.0 & 16 & 14.4 & 12 & 13.5 & & \\
\hline Many problems or cannot function at all & 8 & 4.0 & 4 & 3.6 & 4 & 4.5 & & \\
\hline \multicolumn{9}{|l|}{ Pain or discomfort in the past 4 weeks } \\
\hline No or mild pain or discomfort & 120 & 60.0 & 76 & 68.5 & 44 & 49.4 & \multirow[t]{3}{*}{$2.2(1.2-3.9)$} & \multirow[t]{3}{*}{0.007} \\
\hline Moderate pain/discomfort & 47 & 23.5 & 22 & 19.8 & 25 & 28.1 & & \\
\hline Severe or very severe pain/discomfort & 33 & 16.5 & 13 & 11.7 & 20 & 22.5 & & \\
\hline \multicolumn{9}{|l|}{$\begin{array}{l}\text { Memory or concentration problems in the } \\
\text { past } 4 \text { weeks }\end{array}$} \\
\hline No or few problems & 139 & 69.5 & 82 & 73.9 & 57 & 64.0 & \multirow[t]{3}{*}{$1.8(0.9-3.2)$} & \multirow[t]{3}{*}{0.07} \\
\hline Some problems & 31 & 15.5 & 19 & 17.1 & 12 & 13.5 & & \\
\hline Many or excessive problems & 30 & 15 & 10 & 9.0 & 20 & 22.5 & & \\
\hline \multicolumn{9}{|l|}{$\begin{array}{l}\text { Sleep or relaxing medication in the past } \\
4 \text { weeks }\end{array}$} \\
\hline None & 186 & 93.0 & 105 & 94.6 & 81 & 91.0 & \multirow[t]{2}{*}{$2.1(0.7-6.6)$} & \multirow[t]{2}{*}{0.2} \\
\hline One or more times & 14 & 7.0 & 6 & 5.4 & 8 & 9.0 & & \\
\hline \multicolumn{9}{|l|}{ Pain medication in the past 4 weeks } \\
\hline None & 55 & 27.5 & 32 & 28.8 & 23 & 25.8 & \multirow[t]{2}{*}{$1.09(0.6-2.1)$} & \multirow[t]{2}{*}{0.8} \\
\hline One or more times & 145 & 72.5 & 79 & 71.2 & 66 & 74.2 & & \\
\hline \multicolumn{9}{|l|}{ Antidepressants in the past 4 weeks } \\
\hline None & 190 & 95.0 & 110 & 99.1 & 80 & 89.9 & $17.4(2.0-152)$ & 0.010 \\
\hline One or more times & 10 & 5.0 & 1 & 0.9 & 9 & 10.1 & & \\
\hline Ever thought of suicide & & & & & & & & \\
\hline No & 172 & 86.0 & 105 & 94.6 & 67 & 75.3 & $6.6(2.4-17.9)$ & $<0.001$ \\
\hline Yes & 28 & 14.0 & 6 & 5.4 & 22 & 24.7 & & \\
\hline Ever attempted suicide & & & & & & & & \\
\hline No & 189 & 94.5 & 108 & 97.3 & 81 & 91.0 & $4.0(1.0-16.1)$ & 0.06 \\
\hline Yes & 11 & 5.5 & 3 & 2.7 & 8 & 9.0 & & \\
\hline
\end{tabular}

${ }^{a} \mathrm{OR}$ adjusted for women's age, earning capacity, and 12 years of education. $O R=$ odds ratio; $C l=$ confidence interval.

significant (Table 3 ). The only exception was in the case of women's views towards interference by others outside the family if a husband mistreated his wife, where spousal violence was 2.5 times more likely in women who disagreed with non-interference (OR 2.0; 95\% CI: 1.1-3.8). The majority of women did not accept wife-beating under most of the scenarios presented. However, no significant relationship was found between women's acceptance of wife-beating and spousal violence.

\section{Discussion}

This study presents initial yet important findings related to spousal violence as obtained from $\mathrm{PHC}$ clinics in Saudi Arabia. The frequency of ever experience of spousal violence in our 


\begin{tabular}{|c|c|c|c|c|c|c|c|c|}
\hline \multirow[t]{2}{*}{ Women's gender attitudes } & \multicolumn{2}{|c|}{ Total } & \multicolumn{2}{|c|}{ No spousal violence } & \multicolumn{2}{|c|}{ Spousal violence } & \multirow[t]{2}{*}{ OR $(95 \% \mathrm{Cl})$} & \multirow[t]{2}{*}{$P$-value } \\
\hline & No. & $\%$ & No. & $\%$ & No. & $\%$ & & \\
\hline \multicolumn{9}{|c|}{ Agood wife should obey her husband } \\
\hline Agree & 98 & 49.0 & 59 & 53.2 & 39 & 43.8 & \multirow[t]{2}{*}{$1.2(0.6-2.4)$} & \multirow[t]{2}{*}{0.6} \\
\hline Disagree & 102 & 51.0 & 52 & 46.8 & 50 & 56.2 & & \\
\hline \multicolumn{9}{|c|}{$\begin{array}{l}\text { Family problems should only be } \\
\text { discussed within family }\end{array}$} \\
\hline Agree & 161 & 80.5 & 93 & 83.8 & 68 & 76.4 & \multirow[t]{2}{*}{$1.4(0.6-3.0)$} & \multirow[t]{2}{*}{0.4} \\
\hline Disagree & 39 & 19.5 & 18 & 16.2 & 21 & 23.6 & & \\
\hline \multicolumn{9}{|c|}{$\begin{array}{l}\text { It's important for a husband to show he is } \\
\text { the boss of the house }\end{array}$} \\
\hline Agree & 118 & 59.0 & 68 & 61.3 & 50 & 56.2 & \multirow[t]{2}{*}{$1.5(0.8-2.9)$} & \multirow[t]{2}{*}{0.2} \\
\hline Disagree & 82 & 41.0 & 43 & 38.7 & 39 & 43.8 & & \\
\hline \multicolumn{9}{|c|}{$\begin{array}{l}\text { A woman should not choose her own } \\
\text { friends if her husband disapproves }\end{array}$} \\
\hline Agree & 99 & 49.5 & 57 & 52.3 & 42 & 47.2 & \multirow[t]{2}{*}{$1.2(0.6-2.2)$} & \multirow[t]{2}{*}{0.6} \\
\hline Disagree & 99 & 49.5 & 52 & 47.7 & 47 & 52.8 & & \\
\hline \multicolumn{9}{|c|}{$\begin{array}{l}\text { If a man mistreats his wife, others outside } \\
\text { the family should not interfere }\end{array}$} \\
\hline Agree & 88 & 44.0 & 57 & 51.4 & 31 & 35.2 & \multirow[t]{2}{*}{$2.0(1.1-3.8)$} & \multirow[t]{2}{*}{0.03} \\
\hline Disagree & 111 & 55.5 & 54 & 48.6 & 57 & 64.8 & & \\
\hline \multicolumn{9}{|c|}{ A man has the right to beat his wife: } \\
\hline \multicolumn{9}{|c|}{$\begin{array}{l}\text { If she doesn't finish the house chores as } \\
\text { he wants }\end{array}$} \\
\hline No & 197 & 98.5 & 111 & 100.0 & 86 & 96.6 & \multirow[t]{2}{*}{$\mathrm{n} / \mathrm{a}$} & \multirow[t]{2}{*}{$\mathrm{n} / \mathrm{a}$} \\
\hline Yes & 3 & 1.5 & 0 & 0.0 & 3 & 3.4 & & \\
\hline \multicolumn{9}{|l|}{ If she disobeys him } \\
\hline No & 172 & 86.0 & 92 & 82.9 & 80 & 89.9 & \multirow[t]{2}{*}{$0.8(0.3-2.2)$} & 0.6 \\
\hline Yes & 28 & 14.0 & 19 & 17.1 & 9 & 10.1 & & \\
\hline If she refuses to have sex wit & & & & & & & & \\
\hline No & 184 & 92.0 & 103 & 92.8 & 81 & 92.0 & $0.9(0.3-3.5)$ & 0.9 \\
\hline Yes & 15 & 7.5 & 8 & 7.2 & 7 & 8.0 & & \\
\hline $\begin{array}{l}\text { If she asks him about his rel } \\
\text { with other women }\end{array}$ & & & & & & & & \\
\hline No & 191 & 95.5 & 107 & 98.2 & 84 & 94.4 & $1.1(0.2-7.7)$ & 0.9 \\
\hline Yes & 7 & 3.5 & 2 & 1.8 & 5 & 5.6 & & \\
\hline If he has doubts about his u & & & & & & & & \\
\hline No & 167 & 83.5 & 96 & 87.3 & 71 & 80.7 & $1.6(0.7-3.9)$ & 0.3 \\
\hline Yes & 31 & 15.5 & 14 & 12.7 & 17 & 19.3 & & \\
\hline If he discovers his wife chea & & & & & & & & \\
\hline No & 96 & 48.0 & 59 & 53.2 & 37 & 42.5 & $1.3(0.7-2.5)$ & 0.4 \\
\hline Yes & 102 & 51.0 & 52 & 46.8 & 50 & 57.5 & & \\
\hline
\end{tabular}

${ }^{a} \mathrm{OR}$ adjusted for women's age, earning capacity and 12 years of education. $n / a=$ not applicable; $O R=$ odds ratio; $C l=$ confidence interval.

research sample (44.5\%) was higher than that observed in most other national studies, where spousal violence ranged from $13 \%$ to $34 \%(12,14,15)$.
In the WHO multi-country study, the rate of spousal violence ranged from a low of $13 \%$ to a high of $61 \%$. The variation was attributed to differences in cultural norms related to violence (5). The higher frequency of spousal violence in our study is similar to some other studies in the EMR (24). 
Women in this study reported being subjected to both moderate (slapped, pushed, shoved or pulled by hair) and severe violent acts (kicked, dragged, beaten up, choked or burned). This may explain the higher frequency of injuries related to spousal violence. The fact that only $6.5 \%$ of injured women had disclosed the real reasons for their injuries to a health-care professional may explain why only $9.5 \%$ of injured women received any treatment; a finding that was similar was similar to findings in other EMR studies $(12,14)$.

Our results of significant associations between spousal violence and poor overall health perceptions, recent perceptions of pain and discomfort, use of antidepressants and thoughts of suicide were consistent with that of the WHO multicounty study of worse health perceptions in victims of violence (25). In Palestine, Lebanon and the Syrian Arab Republic, spousal violence victims were more likely to report depression, suicidal thoughts, somatization and more frequent health complaints $(16,18,24)$. However, the absence of a significant association between utilization of health care and spousal violence may reflect the women's reluctance to seek help for spousal violence.

The findings suggest that the containment of spousal violence to the household signal adherence to larger societal and cultural views. The majority of women in the study (80.5\%) viewed family as a private sphere, agreeing that family problems should only be discussed within the family. Interestingly, although approximately half of the participants had traditional gender attitudes, the great majority of women did not accept the husband's right to beat his wife in most scenarios presented. The exception was in case of a wife's infidelity, whereby $51.0 \%$ viewed beating as appropriate, in accordance with the findings in other studies in the EMR $(8,17,24)$. These findings demonstrate that these women generally did not accept spousal violence as an appropriate enactment of male power.

This study illuminates a distinct relationship between the prevalence of spousal violence and women's communication with PHCs. As only 13 women who suffered injuries as a result of spousal violence $(6.5 \%)$ declared the reason for their injuries to a health-care provider it is clear that a gap exists between prevalence of spousal violence and access to services. Women's hesitation to disclose the real reasons for spousal violencerelated injuries has been observed in other studies $(14,24)$ and, considering the prevalence of reporting practices in Saudi Arabia, it points to prevailing traditional gender power structures that construct family patterns and practices as private and outside the purview of public services. In turn, this perception affects women's health and well-being due to their inability to communicate threats in the private sphere to the public one (24).

One of the notable findings of this study was that participating women readily disclosed sensitive information about spousal violence to the study investigator, even though systems and sociocultural norms are in place to discourage women from reporting private family issues publicly in PHCs. This finding was documented in another EMR study (16), providing fertile ground for investigations of the connections between private and public practices regarding spousal violence.

The study design had some limitations in the sampling methods and the potential for bias in participants' responses. The use of convenience sampling may have introduced a selection bias. By sampling from PHCs across Jeddah, we enhanced the probability of gaining access to women of various socioeconomic strata. Nevertheless, the selection of women from free-of-charge PHCs may have restricted our findings to women from middle to lower socioeconomic strata. In Saudi Arabia, affluent women are more likely to use private healthcare services. Because participating women were asked about past experiences, recall bias may have affected their answers. Many women saw the Saudi interviewer as an influential figure with power to assist them in redressing their complaints. Therefore, most women seemed quite willing to divulge sensitive information about their experiences with violence. However, a social desirability effect may have impacted the quality of data obtained.

\section{Conclusion}

Nearly $50 \%$ of women reported ever experience of IPPVAW, an alarming rate that calls for urgent and efficient violence management policies and services. Official restrictions on Saudi women's autonomy may prevent them from accessing needed services. The health-care setting may be one of the few places where women can freely access help. Therefore, health-care professionals trained in documentation and reporting of IPPVAW can improve the surveillance and intervention efforts. The integration of IPPVAW education into health-care provider education curricula, with the goals of promoting an increased awareness of the prevalence, identification of at-risk women and encouraging non-judgemental attitudes, may contribute to a better service provision and creation of a more cohesive link between the private and public sphere (26).

Competing interests: None declared. 


\section{References}

1. Ellsberg M, Heise L. Researching violence against women. A practical guide for researchers and activists. Washington (DC): World Health Organization and Program for Appropriate Technology in Health (PATH); 2005 (http://whqlibdoc.who. int/publications/2005/9241546476_eng.pdf?ua=1, accessed 4 July 2014).

2. Tufts KA. The World Health Organization, United Nations, and Red Cross approaches to intimate partner violence. In: Clements PT, Pierce-Weeks J, Holt KE, Giardino AP, Seedat S, editors. Violence against women: a contemporary examination of intimate partner violence. St Louis: STM Learning, Inc.; 2014.

3. The Global Campaign for Violence Prevention [Internet]. Geneva: World Health Organization; 2008 (http://www.who. int/violence_injury_prevention/violence/global_campaign/ en/, accessed 4 July 2014).

4. Garcia-Moreno C, Jansen HA, Ellsberg M, Heise L, Watts $\mathrm{CH}_{\text {; }}$ WHO Multi-country Study on Women's Health and Domestic Violence against Women Study Team. Prevalence of intimate partner violence: findings from the WHO multi-country study on women's health and domestic violence. Lancet. 2006 Oct 7;368(9543):1260-9. PMID:17027732

5. Hindin MJ, Kishor S, Ansara DL. Intimate partner violence among couples in 10 DHS countries: predictors and health outcomes. Calverton (MD): Macro International Inc.; 2008.

6. Douki S, Zineb SB, Nacef F, Halbreich U. Women's mental health in the Muslim world: cultural, religious, and social issues. J Affect Disord. 2007 Sep;102(1-3):177-89. PMID:17291594

7. Krug EG, Mercy JA, Dahlberg LL, Zwi AB. The world report on violence and health. Lancet. 2002 Oct 5;360(9339):1083-8. PMID:12384003

8. Somach S, Abou Zeid G. Egypt violence against women study. Literature review of violence against women. Washington (DC): United States Agency for International Development; 2009

9. Haj-Yahia MM. Wife abuse and its psychological consequences as revealed by the first Palestinian National Survey on violence against women. J Fam Psychol. 1999;13(4):642-62.

10. Khawaja M, Tewtel-Salem M. Agreement between husband and wife reports of domestic violence: evidence from poor refugee communities in Lebanon. Int J Epidemiol. 2004 Jun;33(3):526-33. PMID:15163639

11. Maziak W, Asfar T. Physical abuse in low-income women in Aleppo, Syria. Health Care Women Int. 2003 Apr;24(4):31326. PMID:12746003

12. Afifi ZE, Al-Muhaideb NS, Hadish NF, Ismail FI, Al-Qeamy FM. Domestic violence and its impact on married women's health in Eastern Saudi Arabia. Saudi Med J. 2011 Jun;32(6):612-20. PMID:21666945
13. Rachana C, Suraiya K, Hisham A-S, Abdulaziz A-M, Hai A. Prevalence and complications of physical violence during pregnancy. Eur J Obstet Gynecol Reprod Biol. 2002 Jun 10;103(1):26-9. PMID:12039459

14. Tashkandi A, Rasheed FP. Wife abuse: a hidden problem. A study among Saudi women attending PHC centres. East Mediterr Health J. 2009 Sep-Oct;15(5):1242-53. PMID:20214138

15. Plichta SB. Intimate partner violence and physical health consequences: policy and practice implications. J Interpers Violence. 2004 Nov;19(11):1296-323. PMID:15534333

16. Usta J, Farver JAM, Pashayan N. Domestic violence: the Lebanese experience. Public Health. 2007 Mar;121(3):208-19. PMID:17174993

17. Diop-Sidibé N, Campbell JC, Becker S. Domestic violence against women in Egypt-wife-beating and health outcomes. Soc Sci Med. 2006 Mar;62(5):1260-77. PMID:16139404

18. Haj-Yahia MM. Implications of wife abuse and battering for self-esteem, depression, and anxiety as revealed by the second Palestinian national survey on violence against women. J Fam Issues. 2000;21(4):435-63.

19. Kishor S, Johnson K. Profiling domestic violence: a multi-country study. Calverton (MD): ORC Macro for MEASURE DHS+; 2004 (http://dhsprogram.com/pubs/pdf/OD31/OD31.pdf, accessed 4 July 2014).

20. Habib SR, Abdel Azim EK, Fawzy IA, Kamal NN, El Sherbini AM. Prevalence and effects of violence against women in a rural community in Minia governorate, Egypt. J Forensic Sci. 2011 Nov;56(6):1521-7. PMID:21827472

21. Ammar N. In the shadows of the pyramids: Domestic violence in Egypt. Int Rev Victimology. 2000;7:29-46.

22. Almosaed N. Violence against women: a cross-cultural perspective. J Muslim Minor Aff. 2004;24:67-88.

23. Jansen HAFM, Watts C, Ellsberg M, Heise L, García-Moreno C. Interviewer training in the $\mathrm{WHO}$ multi-country study on women's health and domestic violence. Violence Against Women. 2004;10(7):831-49.

24. Boy A, Kulczycki A. What we know about intimate partner violence in the Middle East and North Africa. Violence Against Women. 2008 Jan;14(1):53-70. PMID:18096859

25. Ellsberg $\mathrm{M}$, Jansen HAFM, Heise L, Watts $\mathrm{CH}$, Garcia-Moreno C; WHO Multi-country Study on Women's Health and Domestic Violence against Women Study Team. Intimate partner violence and women's physical and mental health in the WHO multi-country study on women's health and domestic violence: an observational study. Lancet. $2008 \mathrm{Apr}$ 5;371(9619):1165-72. PMID:18395577 